\title{
CULTURAL DISTANCE AND BOND PRICING: EVIDENCE IN THE YANKEE AND RULE 144A BOND MARKETS
}

\author{
Hui Zhu \\ University of Ontario Institute of Technology \\ Kelly Cai \\ University of Michigan-Dearborn
}

\begin{abstract}
In this article we examine the impact of cultural distance on the pricing of corporate bonds issued in the United States. We find that greater cultural differences between U.S. investors and foreign issuers increase the cost of debt. We also find that the cost of Rule 144a offers is less sensitive to cultural distance and creditor protection effects because of the different market structure and investor bases in the Yankee and Rule144a bond markets. Our results suggest that cultural differences influence bond pricing through an information asymmetry channel.
\end{abstract}

JEL Classification: G12, G15, G34

\section{Introduction}

In this article we examine whether cultural differences between borrowers and lenders influence non-U.S. firms' cost of debt in the Yankee and Rule 144a bond markets. Studies have identified that cultural differences have a profound impact on corporate financial decisions and economic development. ${ }^{1}$ Although cultural distance can be used to measure the degree to which shared norms and beliefs differ from one country to another, people from dissimilar cultures are less likely to build trust with one another, and there are more uncertainties in predicting the behavior of others as well. Consequently, for corporate bonds issued in the United States by foreign firms, cultural differences may increase the cost of information gathering and may serve as a measure of information asymmetry between creditors (U.S. investors) and issuers (foreign firms).

The literature on the cost of debt suggests that information asymmetry between borrowers and lenders increases the credit premium required by investors (WittenbergMoerman 2010; Derrien et al. 2012). In the context of international capital markets, it has been argued that a relatively high level of differences in accounting disclosure requirements and legal protections is likely to lead to an increase in information

We are grateful to the associate editor (Andy Naranjo) and Eastern Finance Association 2014 conference participants for valuable comments and constructive suggestions.

${ }^{1}$ For example, Fan, Titman, and Twite (2012) suggest that national culture determines the capital structure choice. Zheng et al. (2012) find that even after controlling for legal, political, and financial systems, national culture significantly influences the maturity of corporate debt. 
asymmetry between investors and foreign borrowers. Therefore, investors may demand higher yield spreads to ameliorate this uncertainty, especially to issuers domiciled in countries with weak investor protection provisions (La Porta et al. 1997; Miller and Puthenpurackal 2002; Qian and Strahan 2007; Miller and Reisel 2012).

In this article, we extend the literature by considering the impact of culture distance in determining a foreign firm's cost of debt in the two U.S. corporate bond markets: the public Yankee bond market and the privately placed Rule 144a bond market. We use a sample of Yankee bonds and Rule 144a bonds issued by foreign firms from 37 countries during 1996-2012 as these are two major markets that foreign firms use to borrow U.S. dollars in the United States. ${ }^{2}$

We examine several important issues in the two U.S. corporate bond markets that have not yet been addressed in the literature. First, we test whether a greater cultural difference between the United States and other countries increases the cost of debt for issuers domiciled in non-U.S. countries. Following Kogut and Singh (1988) and Morosini, Shane, and Singh (1998), we measure the multidimensional cultural differences between the United States and other countries by using Hofstede's (2001) four dimension scores: uncertainty avoidance, individualism, masculinity, and power distance. ${ }^{3} \mathrm{We}$ find that greater cultural differences between U.S. investors and foreign domiciled issuers increase the cost of debt in both the Yankee and Rule 144a bond markets. Our findings are robust to controlling for a country's legal environment, financial development, prior U.S. public debt, and equity listing. We interpret our results as consistent with the asymmetric information hypothesis (Wittenberg-Moerman 2010; Halov and Heider 2011; Derrien et al. 2012). Cultural dissimilarities increase the cost of information gathering; thus, bond issuers from countries with a greater cultural difference with the United States may be considered risker by U.S. investors. Therefore, U.S. investors typically require a higher yield for the bonds issued by these foreign firms.

In addition, we address the consequences of the four subcomponents of cultural differences separately. The four subcomponents are defined as the absolute value of the difference between the issuing country and the United States on Hofstede's (2001) four cultural dimensions. We find a positive relation between the cost of debt and uncertainty avoidance subcomponent $(U A I)$, and the individualism subcomponent (IDV). The dimension of uncertainty avoidance measures the level of acceptance of uncertainty and ambiguity (i.e., risk aversion level of a country). In contrast, the individualism dimension is linked to overconfidence behavior (Chui, Titman, and Wei 2010) and overconfidence in the perception of risk (Hackbarth 2008). The results suggest that risk-averse U.S. creditors may demand higher yields when their risk preference and interpretation of risk are different from foreign borrowers.

\footnotetext{
${ }^{2}$ Non-U.S. firms can also borrow in the eurodollar market. However, eurodollar bonds are issued in bearer (unregistered) form, which is different from Yankee bonds and Rule144a bonds. Also, the primary market for eurodollar bonds is in London, not in the United States.

${ }^{3}$ Long-term orientation is a fifth dimension, developed later based on the Chinese Value Survey of students, which covered only 23 countries. Long-term orientation emphasizes a forward-looking perspective. However, because the long-term orientation dimension has a quite different sample coverage as compared to the other four dimensions, it is not comparable to them and thus is excluded from our study.
} 
Second, we test the joint effects of culture distance and creditor rights in determining a foreign firm's cost of debt in the two U.S. corporate bond markets. Consistent with Miller and Puthenpurackal (2002), in the Yankee bond market we find that investors demand a premium on bonds issued by firms that are located in countries with low creditor rights. However, in the Rule 144a market, the creditor rights variable is not significantly related to the cost of the debt. The results are consistent with Ball, Hail, and Vasvari (2013) and reflect the difference in the market structures between the two U.S. corporate bond markets. In the case of the Yankee bond offers, U.S. creditors likely rely more on countrylevel governance institutions for protection, enforcement, and monitoring. However, in the Rule 144a market, private and institutional U.S. investors can obtain privileged access to information. They have the resources and incentives to more closely monitor the borrowers. The reliance on credit rights protection, thus, is not significant. Given the significant effect of creditor rights on the yield spread in the Yankee bond market, it is interesting to empirically examine the joint impact of cultural distance and creditor rights on the pricing of the corporate bonds issued by the non-U.S. firms. Our results suggest that better creditor rights moderate the positive impact of cultural distance on the cost of debt, but it is not large enough to completely offset the influence of cultural distance.

Third, Giannetti and Yafeh (2012) examine the influence of cultural differences on syndicated bank loans. They document that more culturally distant banks offer borrowers smaller loans at higher interest rates. We extend their study by focusing on the effect of cultural distance as it relates to the public Yankee bonds and privately placed Rule 144a bonds. We find that foreign domiciled issuers being more culturally different from U.S. investors prefer to use longer term and smaller debt amounts with high-yield spreads after controlling for a country's legal environment, financial development, prior U.S. public debt, and equity listing.

Last, because our sample period from 1996 to 2012 includes the 1997 Asian financial crisis and the 2008-2009 financial crisis periods, we separate the entire sample into a noncrisis period subsample and a crisis period subsample (1997, 2008, and 2009). We find that the positive relation between cultural distance and the cost of debt holds only for the noncrisis subsample. In the crisis subsample, the relation is significant and negative, which suggests that during these years a greater cultural difference between the United States and another country decreases the cost of debt for issuers domiciled in that country. The results support Erel et al. (2012) and Cai, Jiang, and Lee (2013), who argue that when market conditions are unfavorable, only high-quality issuers have access to the debt market, and the market reacts favorably to successful debt issues during economic downturns. The ability of a culturally distant non-U.S. firm to access the U.S. debt market under challenging conditions favorably reflects the quality of the issuing firm and reduces its cost of debt.

\section{Literature Review and Hypotheses}

\section{The Two U.S. Corporate Bond Markets Accessed by Foreign Firms}

To issue corporate debt in the United States, non-U.S. firms can choose either the Yankee bond market or the Rule 144a market. The Yankee bond market is regulated by U.S. 
regulations and the U.S. Securities and Exchange Commission (SEC). Non-U.S. issuing firms must adhere to similar registration and disclosure requirements as U.S. firms if they choose to issue bonds in the Yankee bond market. Before the offering, firms need to file a registration statement and provide a prospectus including extensive financial information. The financial numbers need to be reconciled with U.S. generally accepted accounting principles (GAAP). The regulations provide some protections to U.S. investors. However, at the same time they increase the issuing cost, as well as the time needed to bring the issue to the market.

The Rule 144a bond market imposes less regulation on the issuing firms. It allows firms to raise U.S. dollar-dominated bonds in the United States as private placements to qualified institutional buyers (QIBs). Rule 144a bond offers do not need to be registered with the SEC. Firms only need to provide basic information and financial information to the prospective purchasers. The financial numbers do not need to be reconciled with U.S. GAAP either. Rule 144a debt provides speedy access to the U.S. corporate bond market. However, it has limited liquidity as Rule 144a offers can only be resold immediately to QIBs.

As documented in Giddy (1994), Fabozzi (2001), and Miller and Puthenpurackal (2002), domestic bond markets have not been a major source of capital raising outside the United States. Therefore, the Yankee and Rule 144a bond markets provide an important avenue for non-U.S. firms to raise debt capital that is not available in their home country. These two bond markets play a major role in the development of the international capital market.

\section{Bond Pricing}

The literature documents that information asymmetry between borrowers and lenders increases the credit premium that investors demand. Borrowers could improve information transparency to reduce the cost of debt financing. For instance, Mansi, Maxwell, and Miller (2011) find that analyst forecasts contain rich information about firm value, suggesting that analyst activity lowers bond pricing even after controlling for the level of corporate disclosures and private information in equity prices.

In the context of international capital markets, it has been argued that a relatively high level of differences in accounting disclosure requirements and legal protections is likely to lead to increased information asymmetry between investors and foreign borrowers. Therefore, investors demand higher yield spreads for this uncertainty, especially to issuers domiciled in countries with weak investor protections (La Porta et al. 1997; Miller and Puthenpurackal 2002; Qian and Strahan 2007; Miller and Reisel 2012). Overall, the literature confirms that country-level differences in legal protections and information availability have been established as an indicator explaining international capital raising.

\section{National Culture}

National culture has been widely used to explain international investment strategy and corporate financial decisions. For instance, Chui, Titman, and Wei (2010) document that high individualism is associated with large trading volume, high volatility, and more 
profit momentum. Zheng et al. (2012) show that firms located in countries characterized by high uncertainty avoidance, collectivism, masculinity, and power distance tend to use more short-term than long-term debt. In addition, Giannetti and Yafeh (2012) document that cultural distance between borrowers and lenders in the syndicated bank loan market increases the loan spread. As these studies demonstrate, greater cultural distance limits familiarity among counterparties and increases the cost of information gathering and, thus, may serve as a proxy for intrinsic information asymmetry.

\section{Hypotheses Development}

Studies (e.g., La Porta et al. 1997; Miller and Puthenpurackal 2002; Qian and Strahan 2007; Miller and Reisel 2012) document that information asymmetry between creditors and borrowers increases the cost of debt. For foreign firms borrowing in the U.S. market, differences in accounting standards, disclosure requirements, cultures, languages, legal protections, and law enforcement are likely to lead to increased information asymmetry between U.S. investors and foreign borrowers. This important feature allows us to extend the link of information asymmetry and the cost of debt by relating cultural differences between U.S. investors and non-U.S. bond issuers.

Cultural distance can be used to measure whether and how much shared norms and beliefs differ from one country to another. A larger cultural distance increases the cost of information gathering. Thus, cultural differences may serve as a measure of information asymmetry between U.S. investors and non-U.S. issuers. We therefore offer hypothesis 1 :

\section{Hypothesis 1: Firms originating in countries with cultural values far from those in the United States experience a higher cost when raising capital in the U.S. corporate bond markets.}

In the context of international capital markets, studies (e.g., La Porta et al. 1997, 2000; Miller and Puthenpurackal 2002) document that country-specific legal protections also play a fundamental role in the cost of raising capital. For example, investors require a higher risk premium for securities originated in countries with weak creditor protection (La Porta et al. 1997, 2000). Miller and Puthenpurackal (2002) provide strong evidence that borrowing firms originated in countries with weak legal protections and rule of law tend to experience higher debt costs in the Yankee bond market. Larger cultural differences from the United States represent a higher degree of uncertainty and tend to increase the risk premium investors in the United States require. On the other hand, having better legal protection is likely to increase the recovery rate when there is a default, thus decreasing the cost of issuing bonds. We therefore expect that better creditor protection decreases the cost of debt by counteracting the influence of cultural differences between their originated countries and the United States. This leads to hypothesis 2:

Hypothesis 2: Better creditor rights moderate the impact of cultural distance on the cost of debt. The costs of debt are higher for firms domiciled in countries that have a large cultural distance from the United States, along with poor creditor rights. 


\section{Data and Variables}

\section{Sample Selection}

We use Securities Data Company (SDC) data from 1996 to 2012 to identify the sample of debts issued in the United States by non-U.S. firms. We use the credit rating of Moody's whenever it is available and use a Standard \& Poor's (S\&P) rating when a Moody's rating is not available. We obtain detailed issue characteristics information such as issue date, issue amount, seniority, country of domicile, and maturity date from SDC. Following the literature (Gao 2011), we delete bonds issued by financial firms (Standard Industrial Classification code $[\mathrm{SIC}]=6 \mathrm{XXX})$.

We merge these bonds with their corresponding cultural values retrieved from Hofstede's (2001) cultural indices. To be included in the sample, the issuing country must have at least five bonds, as well as all four cultural dimension scores. Our final sample has 1,673 bonds issued by 37 countries and captures more countries than previously reported (e.g., Miller and Puthenpurackal 2002; Qi, Roth, and Wald 2010; Gao 2011). We then merge the sample with the information from the Center for Research in Security Prices (CRSP) and provided by the Bank of New York for the foreign firm cross-listing.

\section{Measure of Yield Spread}

For these 1,673 bond issues, we calculate yield spreads, which we use to measure the cost of debt. Yield spread (YIELD) is computed as the bond's offer yield minus the Treasury rate of comparable maturity. The data on the yields of Treasury bonds are obtained from the Federal Reserve Database (FRED). They represent the daily averages of the constantmaturity yield. If the maturity period of a corporate bond does not exactly match that of Treasury bonds, we use the Treasury bonds with the closest maturity.

\section{Measure of Cultural Distance}

Based on cultural distance as defined by Kogut and Singh (1988) and modified by Morosini, Shane, and Singh (1998), we measure national culture distance as the degree to which the cultural norms in one country differ from those in another country. Specifically, we calculate the multidimensional cultural distance between the United States and other countries using Hofstede's (2001) four dimension scores: uncertainty avoidance, individualism, masculinity, and power distance: ${ }^{4}$

$$
C D_{i}=\frac{1}{4} \sqrt{\sum_{j=1}^{4}\left(D_{i, j}-D_{U S, j}\right)^{2}},
$$

\footnotetext{
${ }^{4}$ In particular, the dimension of uncertainty avoidance measures the level of acceptance of uncertainty and ambiguity within a society. A country with a high uncertainty avoidance score is more risk averse. The dimension of individualism focuses on the degree to which a society reinforces individual versus collective achievement and interpersonal relationships. Individualism is linked to overconfidence behavior (Chui, Titman, and Wei 2010), as well as overconfidence in risk perception (Hackbarth 2008). A high masculinity score indicates that the males in that country dominate society and have much more control and power than females. Likewise, the dimension of power distance focuses on the degree of equality/inequality between people within a society. A high power distance suggests that a country accepts and perpetuates inequalities between individuals.
} 
where $C D_{i}$ is the cultural distance for the $i$ th country and $D_{i, j}$ denotes Hofstede's cultural scores for the $i$ th country with a $j$ th cultural dimension.

Two key reasons motivate us to select this measure of cultural distance. First, Hofstede's (2001) four cultural dimensions have been largely adopted for studies in the international business literature (Kwok and Tadesse 2006; Chui and Kwok 2008; Chui, Titman, and Wei 2010; Han et al. 2010). The validity and reliability underlying Hofstede's cultural index make it the best fit for our study. Second, extensive evidence (e.g., Kogut and Singh 1988; Morosini, Shane, and Singh 1998; Giannetti and Yafeh 2012) suggests that the composite single measure of cultural distance accounts for the various aspects of the underlying national cultural scores.

The Yankee and Rule 144a bond markets provide an explicit channel for nonU.S. firms to raise debt in the U.S. capital market. The markets are generally composed of foreign domiciled issuers and U.S. investors. In our unique market setting, the United States is the only host country; U.S. investors account for all unpredicted risks by issuers from dissimilar cultures when pricing bonds issued by non-U.S. firms. The use of the composite single measure of cultural distance, where we calculate the multidimensional culture distance between the United States and other countries using Hofstede's (2001) four dimension scores, allows us to measure the degree of cultural norms between U.S. investors and foreign domiciled issuers and directly capture the information asymmetry between them.

Additionally, studies (e.g., Chui, Titman, and Wei 2010; Li et al. 2013) show that Hofstede's (2001) uncertainty avoidance and individualism cultural dimensions are two of the most relevant culture values influencing corporate risk preference. In an attempt to examine what role, if any, the four cultural components in the measure of cultural distance play in determining the cost of debt in the Yankee and Rule 144a bond markets, we also use the absolute value of the difference between the issuing country and the United States on four dimensions from Hofstede's (2001) cultural indices - UAI, IDV, MAS, and PDIas proxies for alternative culturally distant values. ${ }^{5}$ Figure I shows a country's cultural difference from the United States and the mean yield spreads. It shows that in general, the mean yield spreads are positively related to $C D$.

\section{Country- and Issue-Specific Characteristics}

To better understand the impact of cultural distance on bond yields, it is important to control for other relevant issue-specific and country-level variables. We include variables that are commonly used in the literature. $A M T$ is the logarithm of the dollar size of the net proceeds of the bond issue in millions of dollars. MAT is the logarithm of the issue's maturity in years. $I_{(a a, b b b)}, I_{(b b)}, I_{(b)}$, and $I_{(c)}$ are indicator variables representing Moody's rating of the issue. For example, $I_{(a a, b b b)}$ equals 1 if bonds are rated AA, A, or BBB, and 0 otherwise. $I_{(b b)}$ equals 1 if bonds are rated $\mathrm{BB}$, and 0 otherwise. The AAA dummy variable

\footnotetext{
${ }^{5}$ According to Hofstede's (2001) cultural index, the uncertainty avoidance, individualism, masculinity, and power distance scores for the United States are 46,91, 62, and 40, respectively. In comparison to other countries, the United States has been considered an uncertainty-accepting society, a highly individualistic culture, and a masculine society, and has equality among individuals.
} 


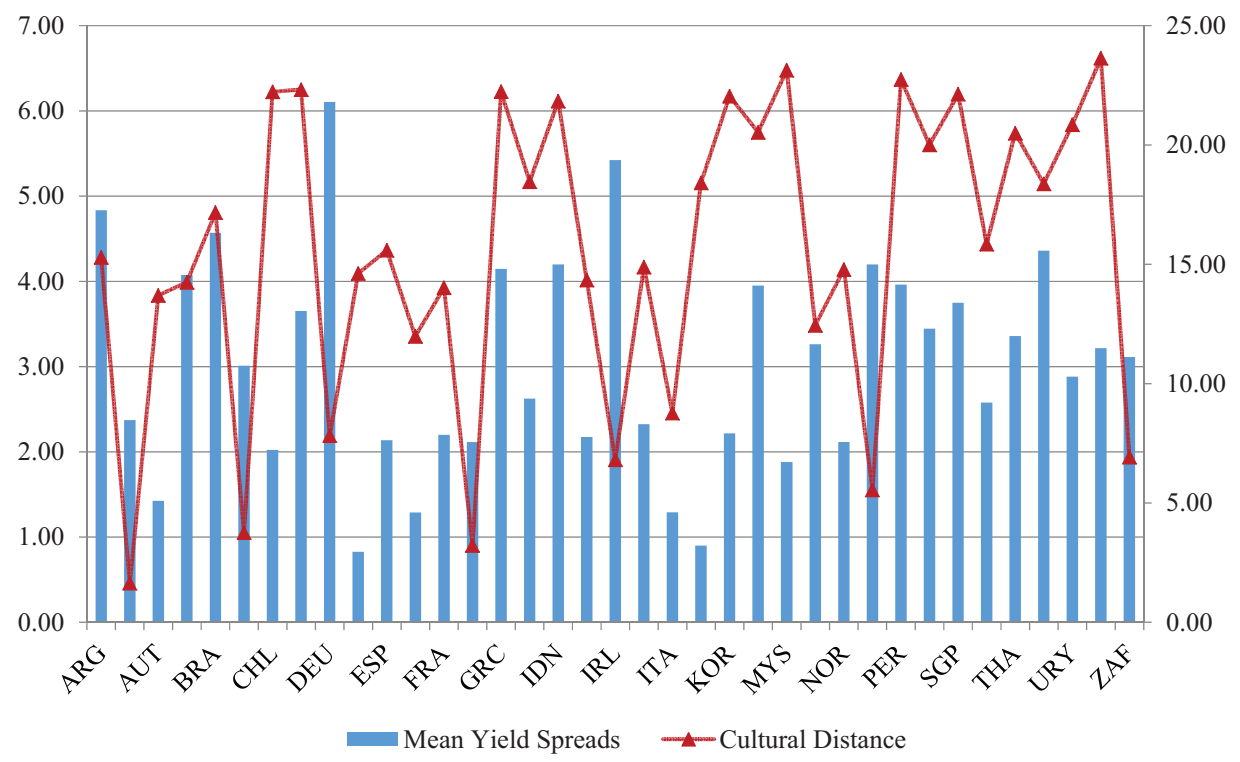

Figure I. Cultural Distance versus Mean Yield Spreads. The figure shows cultural distance and average yield spread by borrower nationality. The $x$-axis is the nation, where the country codes are defined in Table 1 , and the order of the national codes corresponds to columns (1) and (2) in that table. The $y$-axis is the corresponding yield spreads, and the $z$-axis is cultural distance value.

has been dropped to avoid collinearity in the data. $P U T$ is a dummy variable that equals 1 if the bond is putable. SUB equals 1 if the issue is subordinated. COVENANT is a dummy variable that equals 1 if there are covenants associated with the issue. Last, RULE144A is a dummy variable that equals 1 if the issue is in the Rule 144a bond market.

Ball, Hail, and Vasvari (2013) document that the information transparency of foreign firms increases their visibility among U.S. investors. Having shares traded in the United States before the bond issue provides high-quality information, which in turn lowers offering yields for bondholders. Thus, we use LISTING_US as a proxy for whether the firm is listed in the U.S. equity market before the bond offering. For foreign firms that have a history of issuing public debt, they benefit from a good reputation for repaying creditors (Diamond 1989) and improved corporate governance (Stulz 1999). Therefore, these firms have lower borrowing costs. Consequently, we control for seasoned debt, SEASONED_DEBT, which measures whether the firm issued public debt in the U.S. capital markets before the bond issuance. ${ }^{6}$

We also control for the quality of a country's legal system and investor protection. Specifically, we include country-level governance quality control variables. $C R$ measures creditor rights (La Porta et al. 1998), which is an aggregate score ranging from 0 (weak

\footnotetext{
${ }^{6}$ Because near-term prior issues have more information than long-term issues, we also employ an alternative measure, TIME_DEBT, as a proxy for prior debt issues, where TIME_DEBT is defined as the natural logarithm of the number of days between the current and prior issues. We replicate all estimation regressions throughout the study by replacing SEASONED_DEBT variable with the TIME_DEBT variable. The results of cultural distance remain quantitatively similar and the corresponding tables are not reported for brevity.
} 
creditor rights) to 4 (strong creditor rights). $A N T I \_S D$ is an anti-self-dealing index (Djankov et al. 2008), defined as an average of ex ante and ex post private controls of selfdealing, where the former represents the average approval by disinterested shareholders and ex ante disclosure; the latter is the average of disclosure in periodic filings and the ease of proving wrongdoing. $L E G A L \_U K$ measures a country's legal origin based on common law tradition (La Porta et al. 1998) and is an indicator variable equal to 1 if a country's legal origin is English common law, and 0 if the legal origin is French, German, or Scandinavian civil law. NANT_DIR is the revised antidirector right index (Djankov et al. 2008), measured as an aggregate index of shareholder rights.

In addition, if the home market has limited capital market access, paying a higher cost for outside capital is a likely outcome. Thus, following the literature (e.g., Rajan and Zingales 1998; Djankov, McLiesh, and Shleifer 2007), we use FINANCIAL_DEV as an additional explanatory variable to measure the capital market development in the firm's country of origin. We collect financial market development data from the World Development Indicators (WDI) online database. We construct the ratio of stock market capitalization to GDP and the ratio of a country's domestic credit to GDP as proxies for stock market development and credit market development, respectively. We set FINANCIAL_DEV as stock market development whenever stock market development data are available and as credit market development when stock market development data are not available.

Panel A of Table 1 reports Yankee bonds and Rule 144a bonds issued across industries and countries over the 1996-2012 period. Firms from the United Kingdom (270) are the most frequent issuers, followed by Mexico (165) and Brazil (155). Issues placed by firms domiciled in these three countries account for $35 \%$ of the sample. In terms of the industry distribution, we use the 12 Fama-French industry classification codes (Fama and French 1997). The largest number of issues occurs in the manufacturing (565), telephone and television transmission (244), and energy (207) industries. These three industry groups account for $60 \%$ of the sample.

Panel B of Table 1 reports Yankee and Rule 144a bonds issued across years and countries over the 1996-2012 period. In the Yankee bond market, the largest number of issues occurs in 2002 (80), 1999 (73), and 1998 (67). These three years account for $27.88 \%$ of the Yankee bond issues in our sample. In the Rule 144a bond market, the largest number of issues occurs in 2011 (88), 2009 (80), and 1997 (72). These three years account for $27.15 \%$ of the Rule 144 a bond issues in our sample.

Table 2 presents the summary statistics for our key variables. Panel A reports the mean and median of the yield spread, cultural distance, and its subcomponents across country. In general, a higher cultural distance is associated with a greater yield spread. For example, at the country level, Australia has the smallest cultural distance from the United States at 1.64 , with an average yield spread of $2.37 \%$. Venezuela has the greatest cultural distance from the United States at 23.64, with an average yield spread of 3.22\%, which is 85 basis points higher than that of Australia. At the firm level, Cable \& Wireless Optus PTY in Venezuela issued an bond rated A in the United States on May 25, 2000. The offering amount was $\$ 225$ million and the time to maturity was five years. The bond had a yield spread of $2.32 \%$. Corporacion Andina De Fomento in Australia issued a bond rated A- in the United States on June 16, 2000. The offering amount was $\$ 500$ million and the 


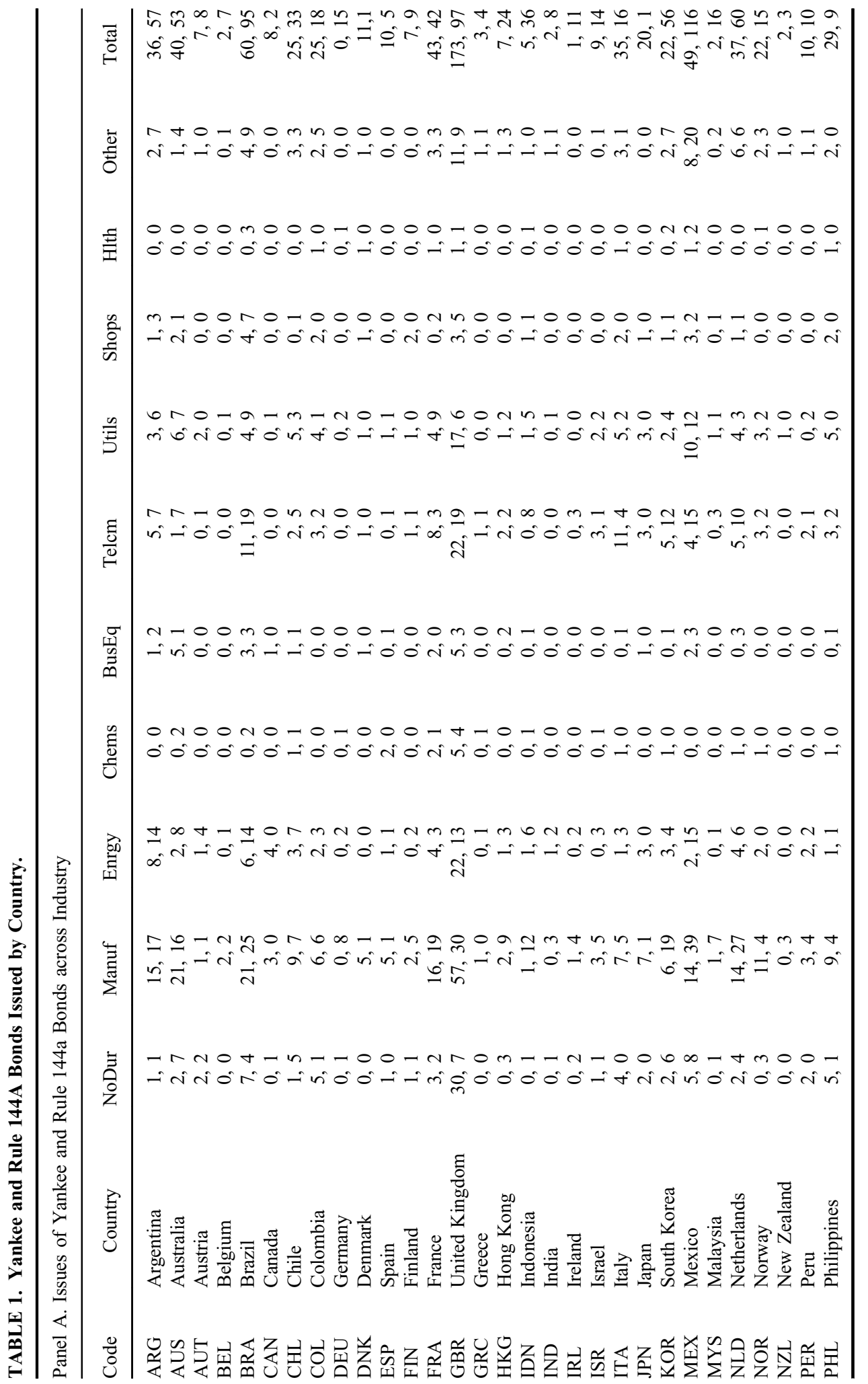




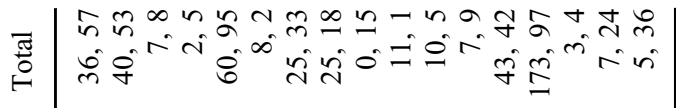

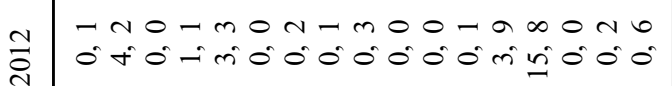

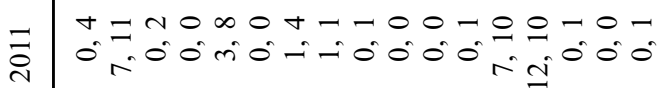

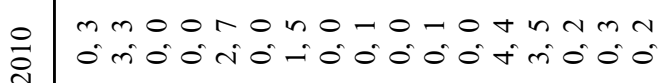

OnnOmomntonommono

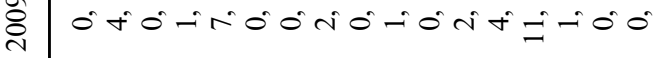

$0-00-0000000 n=0 N n$

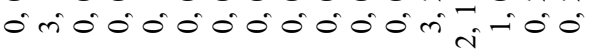

n- $-0-t 00 t-0000$ n 00 t

के 0.

$0+0,0 m-n-0-0,4 n-0,4 m$

O-

ڤิ

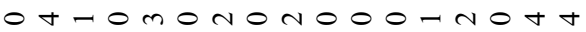

- ती $^{\circ} \mathrm{m}^{\circ} 0^{\circ} 0^{\circ} 0^{\circ} 0^{\circ} 0^{\circ}$ in $0^{\circ} 0^{\circ}$

ষ্ণ

$0-70+0 h-m 000-70 n n$

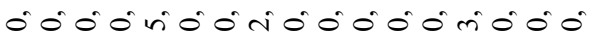

$-60-7=0+7000-n \infty 0 m n$

के viso

$7-n 0-0-0,000-7-0-0$

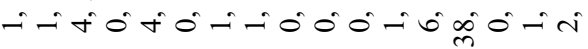

o- $00 \mathrm{mot}-0000 \mathrm{mmomo}$

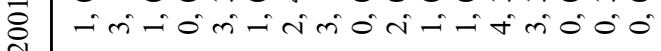

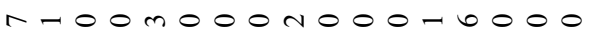

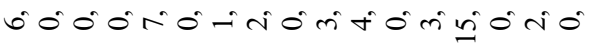



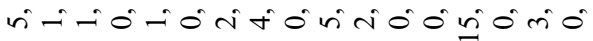

omo-no-noono-nomo ज̆

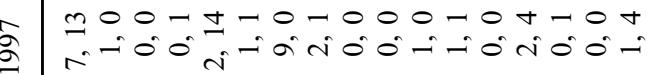

- tmoononno0000-000

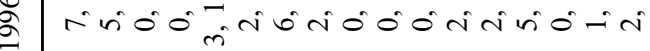

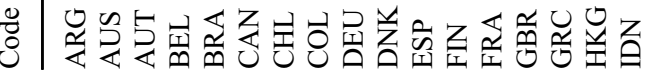




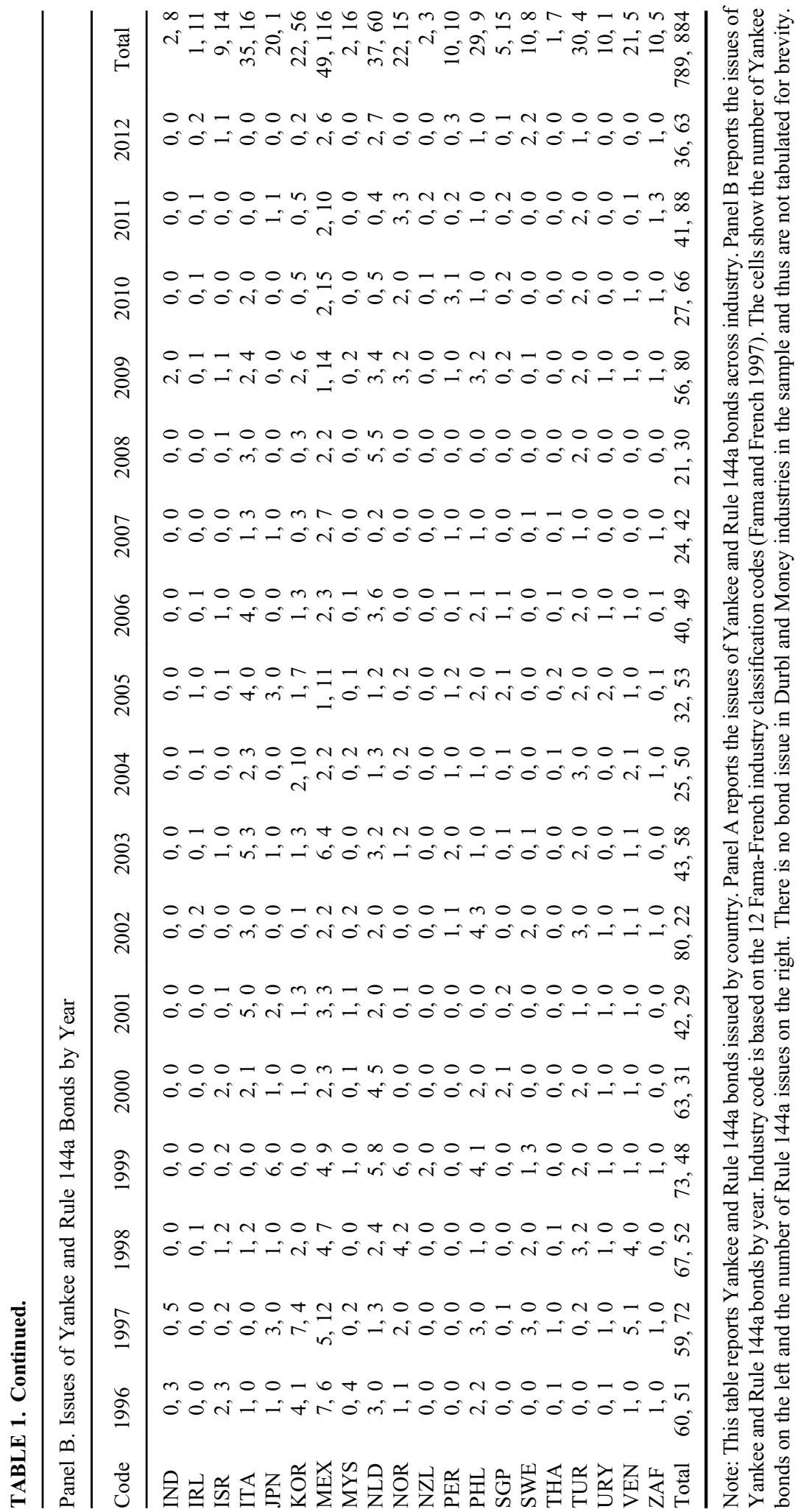




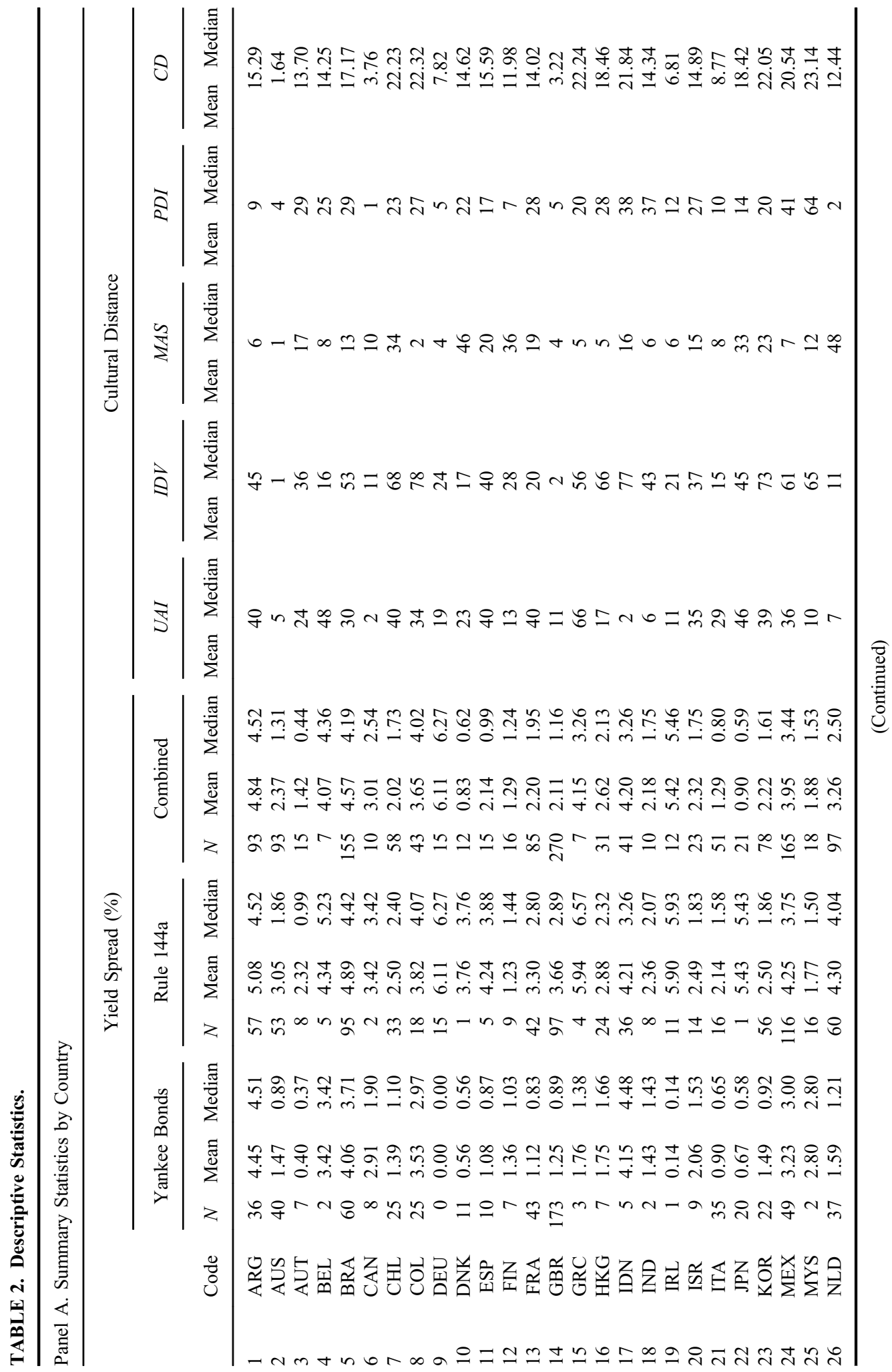




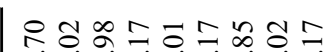

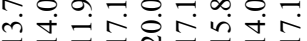
뇨

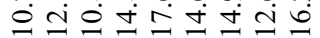
ป윾ㄱㅠㅠㅠㅇㅠ 胥 吾 ปิ



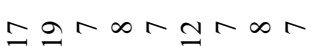

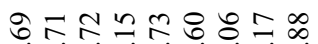
ம்ํ்ப்

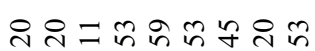
๗ิกิ तेतें in 8.88888:



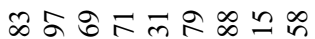

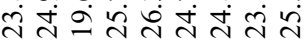

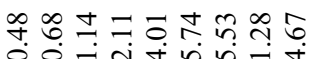

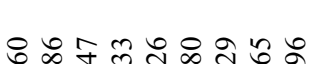
$00-i$ 计 in

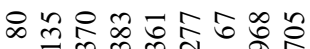
ㄱำ กุก - - i r rin-i

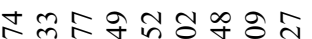
$0-i \mathrm{r} \dot{0}$ in ปั チำ ○े

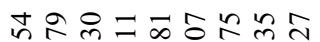



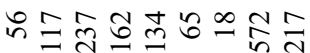
ஃீ

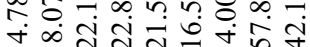

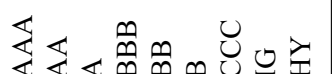
믈 \&ृ. 竞言 
time to maturity was 10 years. The bond had a yield spread of $2.07 \%$. Although these two companies issued bonds at the same time and are from the same industry, the yield spread for Cable \& Wireless Optus PTY is greater than that of Corporacion Andina De Fomen by 25 basis points even though Cable \& Wireless has a better rating. This result may due to a cultural difference as Australia has a much smaller cultural distance from the United States than Venezuela.

Panel B of Table 2 reports the mean and median of the yield spread, cultural distance, and its subcomponents for each rating group. It shows that bonds rated A-, BBB-, and BB are the largest groups, which account for $22.12 \%, 22.89 \%$, and $21.58 \%$ of the sample, respectively. Investment-grade (IG) bonds account for $57.86 \%$ of our sample with an average yield spread of $1.65 \%$, whereas high-yield (HY) grade bonds account for the remaining $42.14 \%$ with an average yield spread of $4.96 \%$. Overall, the yield distribution in our sample supports the evidence that the higher the rating, the lower the cost of debt. Additionally, HY bonds have higher values of UAI, IDV, PDI, and CD, but lower $M A S$ value. The evidence provides further support of the positive relation between the cost of debt and a foreign issuer's cultural differences from the United States.

\section{Empirical Results}

\section{Univariate Tests}

We begin by investigating the unconditional relation between the cost of debt and cultural distance by examining the potential time-varying nature of our sample. Figure IIa illustrates the unconditional correlation between the cost of debt and cultural distance (and number of non-U.S. borrowers) by year. We find that the coefficients on $C D$ are all positive and statistically significant at the $1 \%$ level. These results suggest a positive relation between the cost of debt and cultural distance in the Yankee and Rule 144a bond markets when no variable is controlled.

We next conduct univariate tests to identify the effects of culture differences and credit rights on the yield spread. Panel A of Table 3 reports the mean yield spread for bonds issued by firms from countries that have low ( $C D$ Low) and high ( $C D$ High) cultural differences from the United States. $C D$ Low (High) denotes that the issuing firm is from a country that has a cultural distance value below or equal to (above) the median cultural distance, which is 15.29. CR Low (High) means that the issuing firm is from a country that has a creditor rights index below or equal to (above) the median value, which is value of 2. For issuing firms domiciled in countries that have low credit rights $(C R$ Low group), those originated in $C D$ High countries have a cost of debt that is 77 basis points higher than $C D$ Low countries. The difference in the $C D$ Low group compared to the $C D$ High group is statistically significant at the $1 \%$ level. However, for issuing firms domiciled in countries that have better credit rights ( $C R$ High group), the difference between two cultural difference subgroups is not significant. The univariate test results are consistent with our two hypotheses: (H1) firms originated in countries with cultural value far from those in the United States experience a higher cost when raising debt in the U.S. corporate bond market, and (H2) better creditor rights moderate the impact of cultural distance on the cost of debt. 
a



Number of Bonds $\rightarrow$ Cultural Distance

b



Number of Bonds $\rightarrow$ Cultural Distance

Figure II. Unconditional and Conditional Coefficient Estimates of Cultural Distance. Figures IIa and IIb show the unconditional and conditional coefficients, respectively, of cultural distance from cross-sectional year-by-year regressions. The $x$-axis is the year, the $y$-axis is the number of bonds, and the $z$-axis is the coefficient estimates.

Our sample period is from 1996 to 2012 including the 1997 Asian financial crisis and the 2008-2009 financial crisis periods. To identify how a country's cultural distance from the United States affects the cost of borrowing during market turmoil, we split the sample into two subsamples: the financial crisis period and the noncrisis period. Following the previous literature, (e.g., Michayluk and Neuhauser 2006; Conyon, Judge, and Ussem 2011), we define 1997, 2008, and 2009 as the financial crisis period and the rest of the sample period as the noncrisis period. We find that the univariate test of the differences in mean yield spreads for the $C D$ (Low and High) subsamples exhibit statistically different results in the noncrisis and crisis periods. In the noncrisis period, the results are consistent with the findings in the overall sample. In the crisis period, the results for the $C R$ Low group are consistent with the overall sample. However, the results for the $C R$ High group are different. In the crisis period, issuing firms that domiciled in countries with high credit rights ( $C R$ High group) and a high culture difference ( $C D$ High) experience a 107 basis points lower cost of debt than those from countries with a low culture difference ( $C D$ Low). The results support the findings of Erel et al. (2012) and Cai, Jiang, and Lee (2013). They argue that during poor economic conditions, information problems faced by financially strained firms become more severe, prohibiting them from 
TABLE 3. Mean Yield Spreads for Cultural Distance and Creditor Rights Subsamples.

\begin{tabular}{|c|c|c|c|c|c|c|c|c|}
\hline & \multicolumn{3}{|c|}{$C D$ Low } & \multicolumn{3}{|c|}{$C D$ High } & \multicolumn{2}{|c|}{ Difference } \\
\hline & $N$ & Mean & STD & $N$ & Mean & STD & Difference & $t$-statistics \\
\hline \multicolumn{9}{|c|}{ Panel A. Overall Sample } \\
\hline$C R$ Low & 321 & 2.95 & 2.42 & 623 & 3.72 & 2.17 & $-0.77^{* * *}$ & -4.80 \\
\hline$C R$ High & 545 & 2.48 & 2.37 & 184 & 2.60 & 1.95 & -0.12 & -0.68 \\
\hline Total & 866 & 2.65 & 2.40 & 807 & 3.47 & 2.18 & $-0.81^{* * *}$ & -7.25 \\
\hline \multicolumn{9}{|c|}{ Panel B. Noncrisis Period } \\
\hline$C R$ Low & 255 & 2.95 & 2.53 & 494 & 3.76 & 2.19 & $-0.81^{* * *}$ & -4.34 \\
\hline$C R$ High & 464 & 2.29 & 2.32 & 142 & 2.62 & 1.99 & $-0.33^{*}$ & -1.69 \\
\hline Total & 719 & 2.52 & 2.41 & 636 & 3.51 & 2.19 & $-0.98^{* * *}$ & -7.86 \\
\hline \multicolumn{9}{|c|}{ Panel C. Crisis Period } \\
\hline$C R$ Low & 66 & 2.93 & 1.96 & 129 & 3.57 & 2.13 & $-0.63^{* *}$ & -2.07 \\
\hline$C R$ High & 81 & 3.60 & 2.38 & 42 & 2.53 & 1.83 & $1.07^{* * *}$ & 2.76 \\
\hline Total & 147 & 3.30 & 2.22 & 171 & 3.31 & 2.10 & -0.01 & -0.04 \\
\hline
\end{tabular}

Note: This table reports the comparison of mean yield spreads for bonds issued by firms from countries that have a low culture difference from the United States $(C D$ Low) versus bonds from countries that have a high culture difference from the United States (CD High). Panel A shows the subsample test for the 1996-2012 period. Panels B and $\mathrm{C}$ present the time subsample tests in the noncrisis and crisis periods, respectively. The crisis period includes the 1997 Asian financial crisis and the 2008-2009 financial crisis, and the noncrisis period contains the rest of sample period. $C D$ Low (High) means that the issuing firm is from a country that has a culture distance value below or equal to (above) the median of culture distance, which is 15.29. CR Low (High) means that the issuing firm is from a country that has creditor rights index below or equal to (above) the median of credit rights, which is 2 .

*** Significant at the $1 \%$ level.

** Significant at the 5\% level.

* Significant at the $10 \%$ level.

raising external capital. Under challenging market conditions, a culturally distant firm's access to the U.S. debt market reflects the quality of the firm, which affects their debt costs.

\section{Baseline Models}

We use multivariate models to formally test our two hypotheses. Table 4 reports the baseline regression models. The models include issue-specific and country-level variables, which are widely used in the cost of debt literature to examine the impact of cultural difference and its subcomponents on the cost of debt. In models 1-4, we separately include the four subcomponents of cultural distance (UAI, IDV, MAS, and $P D I$ ). In models 5-7, we incorporate the cultural distance measure $(C D)$, the term that interacts the measure of cultural distance with the investor rights variable $(C D \times C R)$ omitting $C R$, and the interaction term $(C D \times C R)$ omitting $C D$. In all the models, we control year and the 12 Fama-French industry effects. The $t$-statistics are based on twoway cluster-robust standard errors (Cameron, Gelbach, and Miller 2011) with clustering on both the issuing country and the issuing firm. 
TABLE 4. The Effect of Cultural Distance on the Cost of Debt.

\begin{tabular}{|c|c|c|c|c|c|c|c|}
\hline Variables & $\begin{array}{c}(1) \\
Y I E L D\end{array}$ & $\begin{array}{c}(2) \\
Y I E L D\end{array}$ & $\begin{array}{c}(3) \\
Y I E L D\end{array}$ & $\begin{array}{c}(4) \\
Y I E L D\end{array}$ & $\begin{array}{c}(5) \\
Y I E L D\end{array}$ & $\begin{array}{c}(6) \\
Y I E L D\end{array}$ & $\begin{array}{c}(7) \\
Y I E L D\end{array}$ \\
\hline$U A I$ & $\begin{array}{l}0.013^{* * *} \\
(5.95)\end{array}$ & & & & & & \\
\hline$I D V$ & & $\begin{array}{l}0.007^{* * *} \\
(5.88)\end{array}$ & & & & & \\
\hline$M A S$ & & & $\begin{array}{l}-0.010^{* * *} \\
(-3.76)\end{array}$ & & & & \\
\hline$P D I$ & & & & $\begin{array}{c}-0.003 \\
(-0.80)\end{array}$ & & & \\
\hline$C D$ & & & & & $\begin{array}{l}0.019^{* * *} \\
(2.98)\end{array}$ & $\begin{array}{l}0.026^{* * *} \\
(4.47)\end{array}$ & \\
\hline$C D \times C R$ & & & & & & $\begin{array}{c}-0.003 \\
(-1.18)\end{array}$ & $\begin{array}{r}0.004 \\
(1.62)\end{array}$ \\
\hline$C R$ & $\begin{array}{c}-0.009 \\
(-0.20)\end{array}$ & $\begin{array}{l}-0.025 \\
(-0.68)\end{array}$ & $\begin{array}{c}-0.014 \\
(-0.29)\end{array}$ & $\begin{array}{l}-0.082 \\
(-1.56)\end{array}$ & $\begin{array}{l}-0.040 \\
(-0.94)\end{array}$ & & $\begin{array}{l}-0.114^{* *} \\
(-2.42)\end{array}$ \\
\hline FINANCIAL_DEV & $\begin{array}{l}-0.002^{* * *} \\
(-2.70)\end{array}$ & $\begin{array}{l}-0.003^{* * *} \\
(-3.73)\end{array}$ & $\begin{array}{l}-0.002^{* * *} \\
(-2.58)\end{array}$ & $\begin{array}{l}-0.002^{* *} \\
(-2.29)\end{array}$ & $\begin{array}{l}-0.003^{* * *} \\
(-3.31)\end{array}$ & $\begin{array}{l}-0.002^{* * *} \\
(-2.94)\end{array}$ & $\begin{array}{l}-0.002^{* * *} \\
(-2.98)\end{array}$ \\
\hline ANTI_SD & $\begin{array}{l}-0.286 \\
(-1.33)\end{array}$ & $\begin{array}{c}-0.466 \\
(-1.59)\end{array}$ & $\begin{array}{c}-0.187 \\
(-0.73)\end{array}$ & $\begin{array}{l}-0.007 \\
(-0.03)\end{array}$ & $\begin{array}{l}-0.246 \\
(-0.86)\end{array}$ & $\begin{array}{c}-0.249 \\
(-0.84)\end{array}$ & $\begin{array}{c}-0.133 \\
(-0.46)\end{array}$ \\
\hline$L E G A L \_U K$ & $\begin{array}{c}0.178 \\
(1.06)\end{array}$ & $\begin{array}{r}0.243 \\
(1.16)\end{array}$ & $\begin{array}{l}-0.316 \\
(-1.29)\end{array}$ & $\begin{array}{l}-0.044 \\
(-0.21)\end{array}$ & $\begin{array}{r}0.190 \\
(0.90)\end{array}$ & $\begin{array}{l}0.176 \\
(0.83)\end{array}$ & $\begin{array}{l}0.110 \\
(0.48)\end{array}$ \\
\hline NANT_DIR & $\begin{array}{l}0.089^{* *} \\
(2.25)\end{array}$ & $\begin{array}{l}0.117^{\text {*** }} \\
(2.64)\end{array}$ & $\begin{array}{l}0.103^{* *} \\
(2.41)\end{array}$ & $\begin{array}{r}0.063 \\
(1.31)\end{array}$ & $\begin{array}{l}0.102^{* *} \\
(2.21)\end{array}$ & $\begin{array}{l}0.101^{* *} \\
(2.16)\end{array}$ & $\begin{array}{l}0.089^{*} \\
(1.88)\end{array}$ \\
\hline$A M T$ & $\begin{array}{l}-0.070^{* * *} \\
(-3.28)\end{array}$ & $\begin{array}{l}-0.073^{* * *} \\
(-3.54)\end{array}$ & $\begin{array}{l}-0.075^{* * *} \\
(-3.73)\end{array}$ & $\begin{array}{l}-0.078^{* * *} \\
(-3.58)\end{array}$ & $\begin{array}{l}-0.076^{* * *} \\
(-3.39)\end{array}$ & $\begin{array}{l}-0.075^{* * *} \\
(-3.53)\end{array}$ & $\begin{array}{l}-0.078^{* * *} \\
(-3.56)\end{array}$ \\
\hline$M A T$ & $\begin{array}{c}0.053 \\
(1.32)\end{array}$ & $\begin{array}{c}0.009 \\
(0.21)\end{array}$ & $\begin{array}{r}0.047 \\
(1.17)\end{array}$ & $\begin{array}{c}0.042 \\
(1.07)\end{array}$ & $\begin{array}{c}0.018 \\
(0.45)\end{array}$ & $\begin{array}{c}0.018 \\
(0.43)\end{array}$ & $\begin{array}{c}0.027 \\
(0.65)\end{array}$ \\
\hline SEASONED_DEBT & $\begin{array}{l}-0.122^{* *} \\
(-2.08)\end{array}$ & $\begin{array}{l}-0.143^{* * *} \\
(-2.60)\end{array}$ & $\begin{array}{l}-0.125^{* *} \\
(-2.36)\end{array}$ & $\begin{array}{l}-0.102^{*} \\
(-1.84)\end{array}$ & $\begin{array}{l}-0.129^{* *} \\
(-2.30)\end{array}$ & $\begin{array}{l}-0.130^{* *} \\
(-2.23)\end{array}$ & $\begin{array}{l}-0.118^{* *} \\
(-2.11)\end{array}$ \\
\hline LISTING_US & $\begin{array}{c}-0.123 \\
(-1.52)\end{array}$ & $\begin{array}{l}-0.096 \\
(-1.05)\end{array}$ & $\begin{array}{l}-0.086 \\
(-1.01)\end{array}$ & $\begin{array}{l}-0.124^{*} \\
(-1.65)\end{array}$ & $\begin{array}{l}-0.113 \\
(-1.37)\end{array}$ & $\begin{array}{c}-0.119 \\
(-1.36)\end{array}$ & $\begin{array}{l}-0.110 \\
(-1.30)\end{array}$ \\
\hline$I_{(a a, b b b)}$ & $\begin{array}{l}1.130^{* * *} \\
(8.35)\end{array}$ & $\begin{array}{l}1.079^{* * *} \\
(8.90)\end{array}$ & $\begin{array}{l}1.099^{* * *} \\
(8.49)\end{array}$ & $\begin{array}{l}1.104^{* * *} \\
(8.03)\end{array}$ & $\begin{array}{l}1.094^{* * *} \\
(8.34)\end{array}$ & $\begin{array}{l}1.094^{* * *} \\
(8.37)\end{array}$ & $\begin{array}{l}1.098^{* * *} \\
(8.40)\end{array}$ \\
\hline$I_{(b b)}$ & $\begin{array}{l}3.613^{* * *} \\
(30.00)\end{array}$ & $\begin{array}{l}3.446^{* * * *} \\
(33.71)\end{array}$ & $\begin{array}{l}3.473^{* * *} \\
(30.04)\end{array}$ & $\begin{array}{l}3.547^{* * *} \\
(29.52)\end{array}$ & $\begin{array}{l}3.497^{* * *} \\
(29.98)\end{array}$ & $\begin{array}{l}3.487^{* * *} \\
(28.84)\end{array}$ & $\begin{array}{l}3.523^{\text {*** }} \\
(30.58)\end{array}$ \\
\hline$I_{(b)}$ & $\begin{array}{l}5.102^{* * *} \\
(51.81)\end{array}$ & $\begin{array}{l}4.991^{* * *} \\
(67.46)\end{array}$ & $\begin{array}{l}5.010^{* * *} \\
(56.65)\end{array}$ & $\begin{array}{l}5.053^{* * *} \\
(51.38)\end{array}$ & $\begin{array}{l}5.030^{* * *} \\
(55.21)\end{array}$ & $\begin{array}{l}5.028^{* * *} \\
(53.35)\end{array}$ & $\begin{array}{c}5.038^{* * *} \\
(54.71)\end{array}$ \\
\hline$I_{(c)}$ & $\begin{array}{l}4.645^{* * *} \\
(16.07)\end{array}$ & $\begin{array}{l}4.533^{* * *} \\
(15.01)\end{array}$ & $\begin{array}{l}4.559^{* * *} \\
(15.49)\end{array}$ & $\begin{array}{l}4.583^{* * *} \\
(16.18)\end{array}$ & $\begin{array}{c}4.563^{* * *} \\
(15.61)\end{array}$ & $\begin{array}{l}4.556^{* * *} \\
(15.58)\end{array}$ & $\begin{array}{l}4.580^{* * *} \\
(15.80)\end{array}$ \\
\hline PUT & $\begin{array}{l}-0.413^{* * *} \\
(-3.63)\end{array}$ & $\begin{array}{l}-0.448^{* * *} \\
(-4.24)\end{array}$ & $\begin{array}{l}-0.432^{* * *} \\
(-3.75)\end{array}$ & $\begin{array}{l}-0.398^{* * *} \\
(-3.37)\end{array}$ & $\begin{array}{l}-0.426^{* * *} \\
(-3.95)\end{array}$ & $\begin{array}{l}-0.425^{* * *} \\
(-3.89)\end{array}$ & $\begin{array}{l}-0.420^{* * *} \\
(-3.73)\end{array}$ \\
\hline$S U B$ & $\begin{array}{l}-2.480^{*} \\
(-1.71)\end{array}$ & $\begin{array}{l}-2.559^{*} \\
(-1.79)\end{array}$ & $\begin{array}{l}-2.507^{*} \\
(-1.71)\end{array}$ & $\begin{array}{l}-2.553^{*} \\
(-1.87)\end{array}$ & $\begin{array}{l}-2.549^{*} \\
(-1.82)\end{array}$ & $\begin{array}{l}-2.544^{*} \\
(-1.80)\end{array}$ & $\begin{array}{l}-2.559^{*} \\
(-1.86)\end{array}$ \\
\hline COVENANT & $\begin{array}{l}0.163^{*} \\
(1.69)\end{array}$ & $\begin{array}{c}0.163^{*} \\
(1.71)\end{array}$ & $\begin{array}{r}0.146 \\
(1.48)\end{array}$ & $\begin{array}{r}0.154 \\
(1.54)\end{array}$ & $\begin{array}{c}0.163^{*} \\
(1.66)\end{array}$ & $\begin{array}{c}0.165^{*} \\
(1.67)\end{array}$ & $\begin{array}{c}0.158 \\
(1.60)\end{array}$ \\
\hline RULE144A & $\begin{array}{l}0.793^{* * *} \\
(7.94)\end{array}$ & $\begin{array}{l}0.769^{* * *} \\
(8.09)\end{array}$ & $\begin{array}{l}0.800^{* * *} \\
(7.84)\end{array}$ & $\begin{array}{l}0.794^{* * *} \\
(7.95)\end{array}$ & $\begin{array}{l}0.778^{* * *} \\
(7.87)\end{array}$ & $\begin{array}{l}0.781^{* * *} \\
(7.69)\end{array}$ & $\begin{array}{l}0.779^{* * *} \\
(7.80)\end{array}$ \\
\hline
\end{tabular}


TABLE 4. Continued.

\begin{tabular}{lccccccc}
\hline \multirow{2}{*}{ Variables } & $(1)$ & $(2)$ & $(3)$ & $(4)$ & $(5)$ & $(6)$ & $(7)$ \\
Intercept & $Y I E L D$ & YIELD & YIELD & YIELD & YIELD & YIELD & YIELD \\
\hline \multirow{2}{*}{ Observations } & 0.204 & $1.917^{* * *}$ & $0.810^{* * *}$ & $0.880^{* * *}$ & $0.548^{* * *}$ & $0.407^{* * *}$ & $0.865^{* * *}$ \\
$R^{2}$ & $(0.94)$ & $(8.06)$ & $(3.35)$ & $(3.62)$ & $(2.69)$ & $(2.66)$ & $(3.81)$ \\
& 1,673 & 1,673 & 1,673 & 1,673 & 1,673 & 1,673 & 1,673 \\
& 0.670 & 0.670 & 0.668 & 0.666 & 0.667 & 0.668 & 0.667 \\
\hline
\end{tabular}

Note: This table presents the estimation results obtained by regressing the yields spread (YIELD) on cultural distance $(C D)$ and its corresponding subcomponents and on controls of bond characteristics and country variables in the comprehensive set of Yankee and Rule 144a bonds. The Appendix provides the definitions of the regression variables. For the sake of brevity, industry and year controls are included, but the results are not tabulated. The industry controls are based on the 12 Fama-French industry classification codes. The $t$-statistics based on two-way cluster-robust standard errors (Cameron, Gelbach, and Miller 2011) with clustering on both the issuing country and the issuing firm are reported in parentheses.

*** Significant at the $1 \%$ level.

** Significant at the $5 \%$ level.

* Significant at the $10 \%$ level.

In model 1 of Table 4, the coefficient estimate on $U A I$ is positive and statistically significant at the $1 \%$ level, which suggests that issuing firms in countries with a high difference in uncertainty avoidance scores from the United States tend to experience higher debt costs. The effect of $U A I$ is also economically significant. A one standard deviation increase in $U A I$ (14.71) increases the yield spread by $19.12 \%$ (14.71 times $0.013)$. The results suggest that risk-averse U.S. creditors require higher yields when their risk tolerance is different from non-U.S. borrowers.

Model 2 in Table 4 presents the results for the $I D V$ subcomponent. The coefficient on $I D V$ is significant at the $1 \%$ level, suggesting that issuing firms in countries with a high difference in individualism scores from the United States tend to experience higher debt costs. Economically, a one standard deviation increase in $I D V(27.06)$ increases the yield spread by $18.94 \%$ (27.06 times 0.007 ). Studies (e.g., Hackbarth 2008; Chui, Titman, and Wei 2010) document that individualism is linked to overconfidence behavior and overconfidence is related to growth and risk perception bias. The results suggest that riskaverse U.S. creditors demand a higher yield spread when their interpretations of risk are different from non-U.S. borrowers.

In model 3 of Table 4, the coefficient on MAS is negative and statistically significant at the $1 \%$ level. A society with high masculinity scores is more assertive and competitive and shows a big gap between male and female values. The results suggest that U.S. investors require lower yields when their view on gender differences is different from non-U.S. borrowers. Model 4 shows the results on the effect of the power distance subcomponent on the cost of debt. We find that the coefficient on $P D I$ is not statistically significant, which suggests that the power distance subcomponent does not play a role in determining the cost of debt.

In model 5 of Table 4, we test the impact of cultural distance on the cost of debt. The coefficient on $C D$ is statistically significant at the $1 \%$ level. It is also economically significant. A one standard deviation increase in cultural distance (7.14) would imply a $13.57 \%$ ( 7.14 times 0.019$)$ increase in yields. The result implies that the uncertainty 
avoidance and individualism subcomponents mainly contribute to the positive relation between the cost of debt and cultural distance. The larger cultural distance between originate countries of bond issuers and U.S. creditors increases borrowing costs, which supports hypothesis 1 .

In model 6 of Table 4 , the effects of cultural differences between U.S. investors and foreign issuers are tested jointly by the coefficients on $C D$ and $C D \times C R$. It shows that the coefficient on $C D$ is statistically significant at the $1 \%$ level with a magnitude of 0.026 . The result provides strong support for Hypothesis 2 concerning the moderating effect of better investor rights protection in the relation between cultural distance and the cost of debt.

In model 7 of Table 4, we test an interactive slope change in creditor rights via cultural distance by the coefficients on $C R$ and $C D \times C R$. It shows that the coefficient on $C R$ is statistically significant at the $5 \%$ level, with a magnitude of -0.114 , which suggests that better creditor protections decrease the cost of debt by counteracting the influence of cultural differences between their countries of origin and the United States, which is consistent with Hypothesis 2.

Consistent with the literature, in all models in Table 4, we find that bond ratings play an important role in determining the yield spread. All credit rating dummies $\left(I_{(a a, b b b)}\right.$, $I_{(b b)}, I_{(b)}$, and $\left.I_{(c)}\right)$ are economically and statistically significant. A negative relation between the firm's country of origin capital development (FINANCIAL_DEV) and the cost of debt provides empirical evidence that paying more for outside capital is a likely outcome if the home market has limited capital market access. The coefficients for the Rule144A dummy are significant and positive, which suggests that a Rule144a issuance is different from the public offers in explaining the determinants of international capital raising given the opportunity set and other less restrictive offering characteristics of Rule 144a issues.

As Yankee bond and Rule 144a bond markets differ in the different market structure and investor bases, we thus split the sample of Yankee bond and Rule 144a bond offers and redo the baseline regression analysis. Results in Panel A of Table 5 are the same as those in Table 4, which suggests that the combined market results are driven by the Yankee bond market. Panel B of Table 5 shows the results in the Rule 144a market. Results in models 1-5 are consistent with those in Panel A of Table 5. However, models 6 and 7 suggest that the impact of $C R$ on the cost of debt is different in the Rule 144a market. In particular, model 6 shows that neither cultural distance nor an interactive slope change in cultural distance via creditor rights is significant in the Rule 144a bond market. Model 7 shows that neither credit rights nor the interaction term is significant in the Rule 144a bond market.

The impact of $C R$ on the cost of debt in the Yankee and Rule 144a bond markets is consistent with Ball, Hail, and Vasvari (2013) and reflects the difference in the market structures. In the case of the Yankee bond offers, U.S. creditors likely rely more on country-level governance institutions for protection, enforcement, and monitoring. Therefore, better creditor rights moderate the impact of cultural distance on the cost of debt. However, in the Rule 144a market, private and institutional investors in the United States can obtain privileged access to information. They typically have the resources and incentives to more closely monitor borrowers. The reliance on the credit rights protection, 
TABLE 5. The Effect of Cultural Distance on the Cost of Debt.

\begin{tabular}{|c|c|c|c|c|c|c|c|}
\hline Variables & $\begin{array}{c}(1) \\
Y I E L D\end{array}$ & $\begin{array}{c}(2) \\
Y I E L D\end{array}$ & $\begin{array}{c}(3) \\
Y I E L D\end{array}$ & $\begin{array}{c}(4) \\
Y I E L D\end{array}$ & $\begin{array}{c}(5) \\
Y I E L D\end{array}$ & $\begin{array}{c}(6) \\
Y I E L D\end{array}$ & $\begin{array}{c}(7) \\
Y I E L D\end{array}$ \\
\hline \multicolumn{8}{|c|}{ Panel A. The Yankee Bond Market } \\
\hline$U A I$ & $\begin{array}{l}0.011^{* * *} \\
(2.99)\end{array}$ & & & & & & \\
\hline$I D V$ & & $\begin{array}{l}0.013^{* * *} \\
(5.55)\end{array}$ & & & & & \\
\hline$M A S$ & & & $\begin{array}{l}-0.014^{* * *} \\
(-3.62)\end{array}$ & & & & \\
\hline$P D I$ & & & & $\begin{array}{l}0.003 \\
(0.62)\end{array}$ & & & \\
\hline$C D$ & & & & & $\begin{array}{l}0.042^{* * *} \\
(4.03)\end{array}$ & $\begin{array}{l}0.072^{* * *} \\
(6.18)\end{array}$ & \\
\hline$C D \times C R$ & & & & & & $\begin{array}{l}-0.012^{* * *} \\
(-4.89)\end{array}$ & $\begin{array}{l}0.008^{* *} \\
(2.11)\end{array}$ \\
\hline$C R$ & $\begin{array}{l}-0.174^{* *} \\
(-2.50)\end{array}$ & $\begin{array}{l}-0.168^{* * *} \\
(-3.09)\end{array}$ & $\begin{array}{l}-0.138^{*} \\
(-1.96)\end{array}$ & $\begin{array}{l}-0.195^{* * *} \\
(-2.82)\end{array}$ & $\begin{array}{l}-0.184^{* * *} \\
(-3.11)\end{array}$ & & $\begin{array}{l}-0.315^{* * *} \\
(-3.20)\end{array}$ \\
\hline Observations & 789 & 789 & 789 & 789 & 789 & 789 & 789 \\
\hline$R^{2}$ & 0.644 & 0.655 & 0.645 & 0.640 & 0.647 & 0.649 & 0.642 \\
\hline \multicolumn{8}{|c|}{ Panel B. The Rule 144a Bond Market } \\
\hline$U A I$ & $\begin{array}{l}0.011^{* * *} \\
(4.01)\end{array}$ & & & & & & \\
\hline$I D V$ & & $\begin{array}{l}0.003^{* * *} \\
(3.32)\end{array}$ & & & & & \\
\hline$M A S$ & & & $\begin{array}{l}-0.007^{* * *} \\
(-3.14)\end{array}$ & & & & \\
\hline$P D I$ & & & & $\begin{array}{l}-0.000 \\
(-0.11)\end{array}$ & & & \\
\hline$C D$ & & & & & $\begin{array}{l}0.009^{* * *} \\
(2.73)\end{array}$ & $\begin{array}{r}0.007 \\
(1.25)\end{array}$ & \\
\hline$C D \times C R$ & & & & & & $\begin{array}{c}0.001 \\
(0.46)\end{array}$ & $\begin{array}{c}0.003 \\
(1.48)\end{array}$ \\
\hline$C R$ & $\begin{array}{l}0.053^{* *} \\
(2.29)\end{array}$ & $\begin{array}{l}0.025 \\
(1.24)\end{array}$ & $\begin{array}{l}0.034 \\
(1.52)\end{array}$ & $\begin{array}{l}-0.004 \\
(-0.12)\end{array}$ & $\begin{array}{l}0.015 \\
(0.67)\end{array}$ & & $\begin{array}{l}-0.029 \\
(-0.96)\end{array}$ \\
\hline Observations & 884 & 884 & 884 & 884 & 884 & 884 & 884 \\
\hline$R^{2}$ & 0.660 & 0.659 & 0.659 & 0.658 & 0.658 & 0.658 & 0.658 \\
\hline
\end{tabular}

Note: This table reports the regression results by splitting the sample into Yankee and Rule 144a bond issues. For the sake of brevity, all the controls are the same as in Table 4, but the results are not tabulated. The Appendix provides the definitions of the regression variables. The $t$-statistics based on two-way cluster-robust standard errors (Cameron, Gelbach, and Miller 2011) with clustering on both the issuing country and the issuing firm are reported in parentheses.

*** Significant at the $1 \%$ level.

** Significant at the 5\% level.

${ }^{*}$ Significant at the $10 \%$ level.

therefore, is not significant. Models 5-7 in Panel B also show that the cost of debt is less sensitive to the effects of cultural distance in the Rule 144a bond market. This may also result from the different investor bases for the Yankee and Rule 144a bond markets. Given the nature of institutional investors, they might likely be somewhat less sensitive to the cultural distance effect. 
Overall, considering cultural distance as a determinant of borrowing costs, the larger the different codes and norms between non-U.S. borrowers and U.S. investors, the higher the borrowing costs will be. In the Yankee bond market, better protection rights for investors in the non-U.S. country partially offset the influence of cultural distance, but not enough to completely counteract the cost-increasing effects of cultural distance. This finding does not hold in the Rule 144a market. This could be due to the different market structure and investor bases for these two markets.

\section{Robustness Checks}

Cultural differences can increase the information asymmetry between U.S. investors and non-U.S. borrowers, as well as increase the return U.S. investors require for this uncertainty. We conduct tests to ensure the robustness of our results to: (1) nonprice contract terms, (2) time variation, and (3) financial crisis. ${ }^{7}$

\section{Nonprice Contract Terms}

Giannetti and Yafeh (2012) examine the effect of cultural distance on syndicated bank loans and argue that cultural differences influence contracting costs, as well as the nonprice contractual terms. To assess how cultural distance influences nonprice contractual terms, we replicate the main analyses using the maturity of the issue (MAT) and amount of borrowed (AMT) funds as the dependent variables.

Table 6 presents the estimation results for nonprice contract variables-MAT and $A M T$ - as a contrast to model 5 in Table 4. In models 1, 3, and 5, MAT is the dependent variable, and in models 2,4 , and 6, $A M T$ is the dependent variable. The coefficients on $C D$ in models 1 and 5 are statistically significant at the $1 \%$ level, which suggests that U.S. creditors tend to require longer term debt from foreign issuing firms that are more culturally different from the United States. This finding suggests that U.S. investors prefer longer term foreign bonds from firms whose cultural norms are far different from the United States. The coefficients on $C D$ in models 4 and 6 are also statistically significant, which suggests that more culturally distant firms are more likely to offer U.S. creditors lower debt amounts. The evidence supports the concept that U.S. creditors offer more culturally distant foreign borrowers smaller amounts of debt, which complements and is consistent with the findings in the syndicated bank loan market (Giannetti and Yafeh 2012).

\section{Time Variation}

The main analyses address time variation issues by incorporating year-level fixed effects. Given the foundational nature of the cultural distance variable, which does not materially change over time, our main results may overstate the effect of cultural distance. To

\footnotetext{
${ }^{7}$ Thus far, we use the two-way cluster-robust approach (Cameron, Gelbach, and Miller 2011) with clustering at both the firm and country levels throughout the analyses. The results of cultural distance remain quantitatively similar if we use alternative estimation approaches: (1) one-way analysis of variance and (2) hierarchical linear modeling (Raudenbush and Bryk 2002), which include the explanatory and control variables from Table 4 and are not reported for brevity.
} 
TABLE 6. The Effect of Cultural Distance on Nonprice Contract Terms.

\begin{tabular}{|c|c|c|c|c|c|c|}
\hline \multirow[b]{2}{*}{ Variables } & \multicolumn{2}{|c|}{ Yankee Bonds } & \multicolumn{2}{|c|}{ Rule $144 a$} & \multicolumn{2}{|c|}{ Combined } \\
\hline & $\begin{array}{c}(1) \\
M A T\end{array}$ & $\begin{array}{c}(2) \\
A M T\end{array}$ & $\begin{array}{c}(3) \\
M A T\end{array}$ & $\begin{array}{c}(4) \\
A M T\end{array}$ & $\begin{array}{c}(5) \\
M A T\end{array}$ & $\begin{array}{c}(6) \\
A M T\end{array}$ \\
\hline$C D$ & $\begin{array}{l}0.023^{* * *} \\
(4.10)\end{array}$ & $\begin{array}{l}-0.017 \\
(-1.55)\end{array}$ & $\begin{array}{c}0.001 \\
(0.25)\end{array}$ & $\begin{array}{l}-0.017^{* * *} \\
(-5.80)\end{array}$ & $\begin{array}{l}0.015^{* * *} \\
(3.45)\end{array}$ & $\begin{array}{l}-0.010^{* *} \\
(-2.44)\end{array}$ \\
\hline$C R$ & $\begin{array}{l}-0.029 \\
(-1.24)\end{array}$ & $\begin{array}{l}-0.006 \\
(-0.10)\end{array}$ & $\begin{array}{l}0.014 \\
(0.83)\end{array}$ & $\begin{array}{l}0.037 \\
(1.16)\end{array}$ & $\begin{array}{l}0.012 \\
(0.65)\end{array}$ & $\begin{array}{l}0.040 \\
(1.54)\end{array}$ \\
\hline FINANCIAL_DEV & $\begin{array}{c}0.000 \\
(0.44)\end{array}$ & $\begin{array}{l}0.008^{* * *} \\
(4.65)\end{array}$ & $\begin{array}{l}-0.000 \\
(-0.10)\end{array}$ & $\begin{array}{l}0.001^{* * *} \\
(3.10)\end{array}$ & $\begin{array}{l}-0.000 \\
(-0.66)\end{array}$ & $\begin{array}{l}0.002^{* * *} \\
(4.90)\end{array}$ \\
\hline ANTI_SD & $\begin{array}{l}-0.804^{* * *} \\
(-7.04)\end{array}$ & $\begin{array}{l}-0.549^{*} \\
(-1.95)\end{array}$ & $\begin{array}{l}-0.032 \\
(-0.41)\end{array}$ & $\begin{array}{l}0.410^{* *} \\
(2.09)\end{array}$ & $\begin{array}{l}-0.409^{* * *} \\
(-5.66)\end{array}$ & $\begin{array}{l}-0.018 \\
(-0.16)\end{array}$ \\
\hline$L E G A L \_U K$ & $\begin{array}{l}0.453^{* * *} \\
(3.08)\end{array}$ & $\begin{array}{l}-0.250 \\
(-1.04)\end{array}$ & $\begin{array}{c}0.140^{*} \\
(1.77)\end{array}$ & $\begin{array}{l}-0.235^{* * *} \\
(-3.44)\end{array}$ & $\begin{array}{l}0.265^{* *} \\
(2.19)\end{array}$ & $\begin{array}{l}-0.171^{*} \\
(-1.86)\end{array}$ \\
\hline$N A N T \_D I R$ & $\begin{array}{l}0.083^{* *} \\
(2.10)\end{array}$ & $\begin{array}{l}-0.256^{* * *} \\
(-2.94)\end{array}$ & $\begin{array}{l}-0.027 \\
(-1.44)\end{array}$ & $\begin{array}{l}-0.173^{* * *} \\
(-8.31)\end{array}$ & $\begin{array}{r}0.035 \\
(1.32)\end{array}$ & $\begin{array}{l}-0.188^{* * *} \\
(-4.56)\end{array}$ \\
\hline SEASONED_DEBT & $\begin{array}{l}0.222^{* * *} \\
(7.62)\end{array}$ & $\begin{array}{c}0.199^{*} \\
(1.80)\end{array}$ & $\begin{array}{c}0.005 \\
(0.21)\end{array}$ & $\begin{array}{c}0.048 \\
(0.74)\end{array}$ & $\begin{array}{l}0.096^{* * *} \\
(4.83)\end{array}$ & $\begin{array}{l}0.124^{*} \\
(1.66)\end{array}$ \\
\hline LISTING_US & $\begin{array}{l}0.188^{* *} \\
(2.40)\end{array}$ & $\begin{array}{c}0.053 \\
(0.25)\end{array}$ & $\begin{array}{l}-0.001 \\
(-0.03)\end{array}$ & $\begin{array}{l}0.043 \\
(0.45)\end{array}$ & $\begin{array}{r}0.071 \\
(1.08)\end{array}$ & $\begin{array}{c}0.034 \\
(0.19)\end{array}$ \\
\hline$I_{(a a, b b b)}$ & $\begin{array}{l}0.219^{* * *} \\
(4.83)\end{array}$ & $\begin{array}{l}-1.124^{* * *} \\
(-5.45)\end{array}$ & $\begin{array}{l}0.457^{* * *} \\
(9.22)\end{array}$ & $\begin{array}{l}0.187^{* *} \\
(2.03)\end{array}$ & $\begin{array}{l}0.366^{* * *} \\
(7.49)\end{array}$ & $\begin{array}{l}-0.472^{* * *} \\
(-3.93)\end{array}$ \\
\hline$I_{(b b)}$ & $\begin{array}{l}0.343^{\text {*** }} \\
(11.03)\end{array}$ & $\begin{array}{l}-0.987^{* * *} \\
(-9.59)\end{array}$ & $\begin{array}{l}0.276^{* * *} \\
(6.05)\end{array}$ & $\begin{array}{l}-0.089 \\
(-0.68)\end{array}$ & $\begin{array}{l}0.339^{* * *} \\
(8.62)\end{array}$ & $\begin{array}{l}-0.542^{* * *} \\
(-6.28)\end{array}$ \\
\hline$I_{(b)}$ & $\begin{array}{l}0.237^{* * *} \\
(6.55)\end{array}$ & $\begin{array}{l}-0.738^{* * *} \\
(-4.60)\end{array}$ & $\begin{array}{l}0.178^{* * *} \\
(4.47)\end{array}$ & $\begin{array}{l}-0.286^{* * *} \\
(-2.64)\end{array}$ & $\begin{array}{l}0.221^{* * *} \\
(4.98)\end{array}$ & $\begin{array}{l}-0.680^{* * *} \\
(-7.26)\end{array}$ \\
\hline$I_{(c)}$ & $\begin{array}{l}-0.433^{\text {*** }} \\
(-4.35)\end{array}$ & $\begin{array}{l}-2.002^{* * *} \\
(-9.09)\end{array}$ & $\begin{array}{r}0.081 \\
(1.04)\end{array}$ & $\begin{array}{l}-0.656^{* * *} \\
(-6.26)\end{array}$ & $\begin{array}{l}-0.056 \\
(-0.71)\end{array}$ & $\begin{array}{c}-1.281^{* * *} \\
(-14.31)\end{array}$ \\
\hline PUT & $\begin{array}{l}0.560^{* * *} \\
(3.64)\end{array}$ & $\begin{array}{l}-1.287^{* *} \\
(-2.14)\end{array}$ & $\begin{array}{l}0.302^{* * *} \\
(2.85)\end{array}$ & $\begin{array}{c}0.043 \\
(0.60)\end{array}$ & $\begin{array}{l}0.350^{* *} \\
(2.52)\end{array}$ & $\begin{array}{l}-0.516^{* *} \\
(-2.24)\end{array}$ \\
\hline$S U B$ & $\begin{array}{c}0.190 \\
(1.27)\end{array}$ & $\begin{array}{l}-1.814^{* * *} \\
(-8.32)\end{array}$ & $\begin{array}{l}-0.133^{*} \\
(-1.68)\end{array}$ & $\begin{array}{l}0.672^{* * *} \\
(8.47)\end{array}$ & $\begin{array}{l}-0.072 \\
(-0.84)\end{array}$ & $\begin{array}{l}-0.250 \\
(-0.26)\end{array}$ \\
\hline COVENANT & $\begin{array}{l}0.234^{* * *} \\
(7.00)\end{array}$ & $\begin{array}{l}1.539^{* * *} \\
(6.82)\end{array}$ & $\begin{array}{c}0.015 \\
(0.40)\end{array}$ & $\begin{array}{l}0.111^{* *} \\
(2.40)\end{array}$ & $\begin{array}{l}0.147^{* * *} \\
(3.75)\end{array}$ & $\begin{array}{l}0.814^{* * *} \\
(6.76)\end{array}$ \\
\hline RULE144A & & & & & $\begin{array}{r}0.087 \\
(1.38)\end{array}$ & $\begin{array}{l}0.194^{* * *} \\
(2.90)\end{array}$ \\
\hline Intercept & $\begin{array}{l}1.031^{* * *} \\
(9.13)\end{array}$ & $\begin{array}{l}13.530^{* * *} \\
(23.06)\end{array}$ & $\begin{array}{c}1.751^{* * * *} \\
(19.66)\end{array}$ & $\begin{array}{l}13.529^{* * *} \\
(88.76)\end{array}$ & $\begin{array}{l}1.476^{* * *} \\
(11.36)\end{array}$ & $\begin{array}{l}13.965^{\text {*** }} \\
(80.26)\end{array}$ \\
\hline Observations & 789 & 789 & 884 & 884 & 1,673 & 1,673 \\
\hline$R^{2}$ & 0.265 & 0.310 & 0.130 & 0.323 & 0.141 & 0.245 \\
\hline
\end{tabular}

Note: This table presents the estimation results obtained by regressing nonprice contract terms - bond maturity $(M A T)$ and bond size $(A M T)$ - on cultural distance $(C D)$ and controls of bond characteristics and country variables. For the sake of brevity, industry and year controls are included, but the results are not tabulated. The $t$-statistics based on two-way cluster-robust standard errors (Cameron, Gelbach, and Miller 2011) with clustering on both the issuing country and the issuing firm are reported in parentheses.

*** Significant at the $1 \%$ level.

** Significant at the $5 \%$ level.

* Significant at the $10 \%$ level.

alleviate this concern, we examine the relation between the cost of debt and cultural distance by running a series of the cross-sectional year-by-year regressions. Figure IIb shows the extent to which the cultural distance effect varies through time as a contrast to model 5 in Table 4. Consistent with our univariate analysis results in Table 3, we find that 
TABLE 7. The Effect of Cultural Distance on the Cost of Debt: Crisis versus Noncrisis Periods.

\begin{tabular}{|c|c|c|c|c|c|c|}
\hline \multirow[b]{2}{*}{ Variables } & \multicolumn{2}{|c|}{ Yankee Bonds } & \multicolumn{2}{|c|}{ Rule $144 \mathrm{a}$} & \multicolumn{2}{|c|}{ Combined } \\
\hline & $\begin{array}{c}(1) \\
Y I E L D\end{array}$ & $\begin{array}{c}(2) \\
Y I E L D\end{array}$ & $\begin{array}{c}(3) \\
Y I E L D\end{array}$ & $\begin{array}{c}(4) \\
Y I E L D\end{array}$ & $\begin{array}{c}(5) \\
Y I E L D\end{array}$ & $\begin{array}{c}(6) \\
Y I E L D\end{array}$ \\
\hline$C D$ & $\begin{array}{l}-0.044^{* * *} \\
(-4.09)\end{array}$ & $\begin{array}{l}0.057^{* * *} \\
(6.94)\end{array}$ & $\begin{array}{l}-0.066^{* * *} \\
(-6.76)\end{array}$ & $\begin{array}{l}0.021^{* * *} \\
(4.45)\end{array}$ & $\begin{array}{c}-0.077^{* * *} \\
(-10.82)\end{array}$ & $\begin{array}{l}0.032^{* * *} \\
(5.71)\end{array}$ \\
\hline$C R$ & $\begin{array}{l}-0.126 \\
(-1.37)\end{array}$ & $\begin{array}{l}-0.173^{* * *} \\
(-3.78)\end{array}$ & $\begin{array}{l}0.174^{* * *} \\
(3.31)\end{array}$ & $\begin{array}{r}0.001 \\
(0.04)\end{array}$ & $\begin{array}{r}0.027 \\
(0.42)\end{array}$ & $\begin{array}{l}-0.047 \\
(-1.41)\end{array}$ \\
\hline RULE144A & & & & & $\begin{array}{l}1.246^{* * *} \\
(14.69)\end{array}$ & $\begin{array}{l}0.714^{* * *} \\
(7.06)\end{array}$ \\
\hline Observations & 136 & 653 & 182 & 702 & 318 & 1,355 \\
\hline$R^{2}$ & 0.497 & 0.702 & 0.430 & 0.692 & 0.473 & 0.705 \\
\hline
\end{tabular}

Note: This table reports the regression results by splitting the sample period into the crisis and noncrisis periods. Columns (1), (3), and (5) include only the crisis period, and columns (2), (4), and (6) contain the noncrisis period. The crisis and noncrisis periods are defined as in Table 3. For the sake of brevity, all the controls are the same as in Table 4, but the results are not tabulated. The Appendix provides the definitions of the regression variables. The $t$ statistics based on two-way cluster-robust standard errors (Cameron, Gelbach, and Miller 2011) with clustering on both the issuing country and the issuing firm are reported in parentheses.

*** Significant at the $1 \%$ level.

the coefficients on $C D$ are positive and statistically significant in most of the noncrisis years and are negative and statistically significant in the crisis years.

\section{Financial Crisis}

The univariate tests in Table 3 and the year-by-year variations in Figure IIb show that the relation between the cost of debt and cultural distance varies during the crisis and noncrisis periods examined. To alleviate the concern that the recent financial crisis interferes with our results, we split the entire sample into crisis period and noncrisis period subsamples and follow the empirical approach in model 5 of Table 4 to avoid potential biases that may derive from the financial crisis. Estimates in Table 7 show that the issuing firms in a country with cultural norms far different from the United States tend to experience higher borrowing costs in the noncrisis period. However, this relation is reversed in the financial crisis period. The results are consistent with Tables 3 and 6 and support the findings by Erel et al. (2012) and Cai, Jiang, and Lee (2013). Under challenging economic conditions, the ability of a culturally distant firm to access the U.S. debt market reflects the quality of the firm and affects its cost of debt.

\section{Conclusions}

In this article we examine the important role of cultural distance in bond pricing. Employing a sample of Yankee and Rule144a bonds from 37 countries for the 1996-2012 period, we find that greater cultural distance from the United States increases the cost of debt financing. Our initial inferences hold while controlling for a country's legal environment, financial development, prior U.S. public debt, and equity listing. Our results 
suggest that more uncertainties in predicting the behavior of others with greater distance may result from differences in norms and beliefs, which in turn influences bond pricing through an information asymmetry channel.

Our article contributes to the literature in three ways. First, we demonstrate that cultural distance affects the pricing of bonds issued by non-U.S. firms in the two U.S. corporate bond markets - public Yankee bonds and privately placed Rule 144a bonds. The results provide evidence that foreign domiciled issuers with cultural values that greatly differ from those in the United States face higher yield spreads when raising capital in these two markets.

Second, we test the joint role of better legal protection and cultural distance and how they affect bond pricing. We find that better creditor protection moderates the influence of cultural distance on the cost of debt, but it is not large enough to completely negate the impact of cultural distance. Consistent with the literature (e.g., Miller and Puthenpurackal 2002; Ball, Hail, and Vasvari 2013), however, this finding only holds in the Yankee bond market. One interpretation of this finding is that the two U.S. corporate bond markets accessed by foreign firms differ in their regulatory requirements, information provision, investor bases, and investors' ability to monitor. Under the different investor bases, institutional investors might likely be somewhat less sensitive to the effect of cultural distance between countries.

Finally, to the extent that more culturally distant banks offer borrowers smaller loans in the syndicated loan market (Giannetti and Yafeh 2012), we show that foreign domiciled issuers that are more culturally different from the United States prefer to use longer term and smaller debt amounts in the Yankee and Rule 144a bond markets.

\section{Appendix: Variable Definitions}

\begin{tabular}{ll}
\hline Variables & Descriptions \\
\hline YIELD & $\begin{array}{c}\text { Yield spread is computed as the bond's offer yield over the Treasury rate of comparable } \\
\text { maturity } \\
\text { The absolute value of the difference between the issuing country and the United States } \\
\text { on Hofstede's (2001) cultural index of uncertainty avoidance } \\
\text { The absolute value of the difference between the issuing country and the United States } \\
\text { on Hofstede's cultural index of individualism } \\
\text { The absolute value of the difference between the issuing country and the United States } \\
\text { on Hofstede's cultural index of masculinity } \\
\text { The absolute value of the difference between the issuing country and the United States } \\
\text { on Hofstede's cultural index of power distance } \\
\text { Cultural distance is calculated as a multidimensional measure that estimated the distance } \\
\text { between the United States and other countries along Hofstede's four dimension scores } \\
\text { Creditor rights: aggregate score ranges from 0 (weak creditor rights) to } 4 \text { (strong creditor } \\
\text { rights) } \\
\text { Financial development measures the ratio of country's stock market capitalization over } \\
\text { its GDP, where stock market capitalization is defined as the summation of share price } \\
\text { times the number of shares outstanding of each listed stock }\end{array}$ \\
FINANCIAL_DEV &
\end{tabular}


Appendix. Continued.

\begin{tabular}{|c|c|}
\hline Variables & Descriptions \\
\hline ANTI_SD & $\begin{array}{l}\text { Anti-self-dealing index: average of ex ante and ex post private control of self-dealing, } \\
\text { where the former represents the average of approval by disinterested shareholders and } \\
\text { ex ante disclosure and the latter is the average of disclosure in periodic filings and } \\
\text { ease of proving wrongdoing }\end{array}$ \\
\hline$L E G A L \_U K$ & $\begin{array}{l}\text { Dummy variable equals } 1 \text { if a country's legal origin is English common law, and } 0 \text { if the } \\
\text { legal origin is French, German, or Scandinavian civil law }\end{array}$ \\
\hline NANT_DIR & $\begin{array}{l}\text { Revised antidirector rights index: an aggregate index of shareholder rights and is formed } \\
\text { by summing the following (1) votes by mail, (2) shares not deposited, (3) cumulative } \\
\text { voting, (4) oppressed minorities, (5) preemptive rights, and (6) capital required to call } \\
\text { a meeting }\end{array}$ \\
\hline$A M T$ & $\begin{array}{l}\text { Issue size: it is the logarithm of the dollar size of the net proceeds of the bond issue in } \\
\text { millions of dollars }\end{array}$ \\
\hline$M A T$ & Maturity: it is the logarithm of the issue's maturity in years \\
\hline SEASONED_DEBT & $\begin{array}{l}\text { Dummy variable equals } 1 \text { if the firm issued debt in the U.S. market before the bond } \\
\text { offering, and } 0 \text { otherwise }\end{array}$ \\
\hline LISTING_US & Dummy variable equals 1 if the firm listed in the United States before the bond offering \\
\hline$I_{(a a, b b b)}$ & 1 if bonds are rated $\mathrm{AA}, \mathrm{A}$, or $\mathrm{BBB}$, and 0 otherwise \\
\hline$I_{(b b)}$ & 1 if bonds are rated $\mathrm{BB}$, and 0 otherwise \\
\hline$I_{(b)}$ & 1 if bonds are rated $\mathrm{B}$, and 0 otherwise \\
\hline$I_{(c)}$ & 1 if bonds are rated $\mathrm{CCC}$ or below, and 0 otherwise \\
\hline PUT & 1 if the bond is putable, and 0 otherwise \\
\hline$S U B$ & 1 if the bond is subordinate bond, and 0 otherwise \\
\hline COVENANT & 1 if the bond has covenants, and 0 otherwise \\
\hline RULE144A & 1 if the bond is Rule $144 \mathrm{a}$ offer, and 0 otherwise \\
\hline
\end{tabular}

\section{References}

Ball, R. T., L. Hail, and F. P. Vasvari, 2013, Equity cross-listings in the U.S. and the price of debt, Paper presented at the CELS 2009 4th Annual Conference on Empirical Legal Studies.

Cai, K., X. Jiang, and H. Lee, 2013, Debt IPO waves, investor sentiment, market conditions, and issue quality, Journal of Financial Research 36, 435-52.

Cameron, A. C., J. B. Gelbach, and D. L. Miller, 2011, Robust inference with multiway clustering, Journal of Business and Economic Statistics 29, 238-49.

Chui, A. C. W., and C. C. Y. Kwok, 2008, National culture and life insurance consumption, Journal of International Business Studies 39, 88-101.

Chui, A. C. W., S. Titman, and K. C. J. Wei, 2010, Individualism and momentum around the world, Journal of Finance 65, 361-92.

Conyon, M., W. Judge, and M. Ussem, 2011, Corporate governance and the 2008-2009 financial crisis, Corporate Governance: An International Review 19, 399-404.

Derrien, F., G. Hilary, A. Kecskes, and S. A. Mansi, 2012, Information asymmetry, credit events and the cost of debt, Working paper, INSEAD.

Diamond, D. W. 1989, Reputation acquisition in debt markets, Journal of Political Economy 97, 828-62.

Djankov, S., R. La Porta, F. Lopez-de-Silanes, and A. Shleifer, 2008, The law and economics of self-dealing, Journal of Financial Economics 88, 430-65.

Djankov, S., C. McLiesh, and A. Shleifer, 2007, Private credit in 129 countries, Journal of Financial Economics 84, 299-329.

Erel, I., B. Julio, W. Kim, and M. Weisback, 2012, Macroeconomic conditions and capital raising, Review of Financial Studies 25, 341-76.

Fabozzi, F. J. 2001. The Handbook of Fixed Income Securities, 6th ed. (McGraw-Hill, New York).

Fama, E. F., and K. R. French, 1997, Industry costs of equity, Journal of Financial Economics 43, $153-93$. 
Fan, J. P. H., S. Titman, and G. Twite, 2012, An international comparison of capital structure and debt maturity choices, Journal of Financial and Quantitative Analysis 47, 23-56.

Gao, Y. 2011, The Sarbanes-Oxley Act and the choice of bond market by foreign firms, Journal of Accounting Research 49, 933-68.

Giannetti, M., and Y. Yafeh, 2012, Do cultural differences between contracting parties matter? Evidence from syndicated bank loans, Management Science 58, 365-83.

Giddy, I. 1994, Global Financial Markets (D.C. Heath, Lexington, MA).

Hackbarth, D. 2008, Managerial traits and capital structure decisions, Journal of Financial and Quantitative Analysis 43, 843-81.

Halov, N., and F. Heider, 2011, Capital structure, risk and asymmetric information, Quarterly Journal of Finance 1 , 767-809.

Han, S., T. Kang, S. Salter, and Y. K. Yoo, 2010, A cross-country study on the effects of national culture on earnings management, Journal of International Business Studies 41, 123-41.

Hofstede, G. H. 2001, Culture's Consequences: Comparing Values, Behaviors, Institutions, and Organizations across Nations (Sage, Thousand Oaks, CA).

Kogut, B., and H. Singh, 1988, The effect of national culture on the choice of entry mode, Journal of International Business Studies 19, 411-32.

Kwok, C. C. Y., and S. Tadesse, 2006, National culture and financial systems, Journal of International Business Studies 37, 227-47.

La Porta, R., F. Lopez-de-Silanes, A. Shleifer, and R. W. Vishny, 1997, Legal determinants of external finance, Journal of Finance 52, 1131-50.

La Porta, R., F. Lopez-de-Silanes, A. Shleifer, and R. W. Vishny, 1998, Law and finance, Journal of Political Economy 106, 1113-55.

La Porta, R., F. Lopez-de-Silanes, A. Schleifer, and R. W. Vishny, 2000, Investor protection and corporate governance, Journal of Financial Economics 58, 3-27.

Li, K., D. Griffin, H. Yue, and L. Zhao, 2013, How does culture influence corporate risk-taking? Journal of Corporate Finance 23, 1-22.

Mansi, S. A., W. F. Maxwell, and D. P. Miller, 2011, Analyst forecast characteristics and the cost of debt, Review of Accounting Studies 16, 116-42.

Michayluk, D., and K. Neuhauser, 2006, Investor overreaction during market declines, Journal of Financial Research 29, 217-34.

Miller, D. P., and J. J. Puthenpurackal, 2002, The costs, wealth effects, and determinants of international capital raising: Evidence from public Yankee bonds, Journal of Financial Intermediation 11, 455-85.

Miller, D. P., and N. Reisel, 2012, Do country-level investor protections affect security-level contract design? Evidence from foreign bond covenants, Review of Financial Studies 25, 408-38.

Morosini, P., S. Shane, and H. Singh, 1998, National cultural distance and cross-border acquisition performance, Journal of International Business Studies 29, 137-58.

Qi, Y., L. Roth, and J. Wald, 2010, Political rights and the cost of debt, Journal of Financial Economics 95, $202-26$.

Qian, J., and P. E. Strahan, 2007, How laws and institutions shape financial contracts: The case of bank loans, Journal of Finance 62, 2803-34.

Rajan, R. G., and L. Zingales, 1998, Financial dependence and growth, American Economic Review 88, 559-86.

Raudenbush, S. W., and A. S. Bryk, 2002. Hierarchical Linear Models: Applications and Data Analysis Methods, Advanced Quantitative Techniques in the Social Science Series (Sage, Thousand Oaks, CA).

Stulz, R. 1999, Globalization, corporate finance, and the cost of capital, Journal of Applied Corporate Finance 12, $8-25$.

Wittenberg-Moerman, R. 2010, The impact of information asymmetry on debt pricing and maturity, Working paper, University of Chicago.

Zheng, X., S. El Ghoul, O. Guedhami, and C. C. Y. Kwok, 2012, National culture and corporate debt maturity, Journal of Banking and Finance 36, 468-88. 
